\title{
the question of desirability: how is education a risk?
}

\author{
magda costa-carvalho ${ }^{1}$ \\ nica-universidade dos açores/ifilnova, portugal
}

\section{abstract}

Gert Biesta claims that education involves introducing young people to a pathway from what they want to what it is good for them to want, offering the conditions for children to cross from the former to the latter. This shift from a realm of individual desires to the realm of the desirable constitutes a "de-centered existence". Since there is an undeniable normative dimension in this view, it seemed important to search for the guiding values or principles that frames it. In his ICPIC talk, G. Biesta refers to the Levinasian concept of responsibility, identifying individual desires (children's desires) with the egological way of existence. In his 2014's book, The beautiful risk of education, Biesta mentions the concept of educational wisdom (educators' wisdom), through an Aristotelian standpoint. In either perspective, the author grants normative privileges to adults, claiming that, in an educational environment, adults have the responsibility to be educators and not learners. We follow from here to question Biesta's statement of education as a risk, since if there are evaluative standards according to which educators can orient their practices, as well as students behaviors (either the responsibility in face of the Other or the ability to make good and wise judgments), how can one still talk about a risk in education? We end up our commentary by looking for deeper meanings for the concept of risk in education.

keywords: education; desirable; normative; risk.

\section{a questão da desejabilidade: como é a educação um risco?}

resumo

Gert Biesta defende que a educação consiste em apresentar às crianças um caminho que vai daquilo que elas querem até àquilo que é bom que elas queiram, oferecendo-lhes as condições para que passem do primeiro ao segundo. Esta passagem de um reino de desejos individuais para $o$ reino do desejável constitui, para o autor, uma "existência des-centrada". Uma vez que existe uma dimensão normativa inegável nesta perspectiva, pareceu-nos relevante procurar os valores e princípios que a orientam. Na sua conferência no ICPIC, G. Biesta refere-se ao conceito levianasiano de responsabilidade, identificando os desejos individuais (das crianças) com o modo de existência egológico. No seu livro de 2014, The beautiful risk of education, o autor menciona o conceito de sabedoria educacional (dos adultos), a partir de uma perspectiva aristotélica. Em ambas as leituras, Biesta concede privilégios normativos aos adultos, afirmando que, num ambiente educativo, estes têm a responsabilidade de ser educadores e não "aprendentes" (learners). A partir deste contexto, questionamos a afirmação da educação como

\footnotetext{
${ }^{1}$ E-mail: magda.ep.teixeira@uac.pt
} 
um risco. Uma vez que, segundo o autor, os professores e educadores têm ao seu dispor padrões normativos de avaliação pelos quais devem orientar as suas práticas, bem como os comportamentos dos alunos (seja a responsabilidade diante do Outro, seja a capacidade de produzir bons juízos), como se poderá ainda falar da educação como risco? Terminamos o nosso comentário procurando significados mais profundos para o conceito de risco em educação.

palavras-chave: educação; desejável; normativo; risco

\section{la cuestión de la deseabilidad: ¿cómo la educación es un riesgo?}

resumen

Gert Biesta defiende que la educación consiste en presentar a los niños un camino que va de aquello que ellos quieren a aquello que es bueno que ellos quieran, ofreciéndoles las condiciones para que pasen de lo primero a lo segundo. Este pasaje de un reino de los deseos individuales para el reino de lo deseable constituye para el autor una "existencia des-centrada". Una vez que existe una dimensión normativa innegable en esta perspectiva, nos pareció relevante buscar los valores y principios que la orientan. En su conferencia en el Congreso del ICPIC, G. Biesta, se refiere al concepto levinasiano de responsabilidad, identificando los deseos individuales (de los niños) como el modo de existencia egológico. En su libro del 2014, El hermoso riesgo de la educación, el autor menciona el concepto de sabiduría educacional (de los adultos) a partir de una perspectiva aristotélica. En ambas lecturas, Biesta concede a los adultos privilegios normativos afirmando que, en un ambiente educativo, estos tienen la responsabilidad de ser educadores y no "aprendices" (learners). A partir de ahí, cuestionamos su afirmación de la educación como riesgo, una vez que si, según el autor, los educadores y los profesores tienen a su disposición patrones normativos de evaluación a partir de los cuales deben orientar su práctica, tanto como los comportamientos de los alumnos (sea la responsabilidad frente del Otro, sea la capacidad de producir buenos juicios), ¿cómo podría aún hablarse aún de la educación como un riesgo? Terminamos nuestro comentario buscando significados más profundos para el concepto de riesgo en educación

palabras clave: educación; deseable; normativo; riesgo. 
the question of desirability: how is education a risk?

I would like to start this commentary by thanking Professor Gert Biesta's keynote presentation in the last ICPIC Conference, for it provided varied food for thought, as it is well expressed in this dossier. Biesta's analyses of the work carried out in Philosophy for Children (P4C) and the questions he poses the community of its practitioners are, in my view, very important ones. This is the kind of engaged inquiry that does not happen often, but should always be very welcomed, for it comes from someone who, despite not being in the specific field of $\mathrm{P} 4 \mathrm{C}$, is acquainted with some of its readings and has a deeper commitment to the broader area of Education.

I also want to congratulate the Editors of childhoodEphilosophy, Walter Kohan and David Kennedy, for the initiative of taking Biesta's talk a lot further. By providing the conditions for this dossier, they will keep the ICPIC Conference alive for many more years: not only for allowing the journal readers (specifically those who could not attend the Conference) to get closer to one of the keynote talks, but also for putting in practice one of P4C main concerns, namely listening to others and building on their ideas. I hope this is just a start and that the dialogue keeps going on, raising core issues to discuss, either in favor of P4C or for the benefit of children.

Gert Biesta stated on his talk that education is about questioning and transforming human beings in such a way that it allows them to put their own desires in perspective. In doing so, subjects open a dialogical existence with what transcends their strict egos, facing the immunity and resistance of their fellow human beings, of other beings (plants and other animals) or simply of the world as such. We may say that encounter and dialogue are two main features of the author's view on schools and education.

In Biesta's framework, education involves introducing young people to a pathway from what they want to what it is good for them to want, offering the conditions for them to cross from the former to the latter. The shift from a realm of individual desires to the realm of the desirable is what Biesta calls a "de-centered 
existence" or, using a more controversial expression, "grown-up-ness". This would be a kind of regulative ideal for all educational practices. To be de-centered, or to live in a de-centered way, is to be able to put the desirable before the desired.

A grown-up subject would, then, be a human being who refuses to live in an egocentric way, re-orienting his/her life toward the world and not just toward him/herself. This ideal human being would be someone who knows which of his/her desires are desirable, nurturing them and suspending all the others. In a different talk, G. Biesta (2017) refers to it as the process of reworking our desires.

The present perspective on education necessarily opens up to a normative dimension: the question of what constitutes the good life, of what should be the guiding values or principles. As G. E. Moore states, the concept of "desirable" refers to that what ought to, or deserves to, be desired (MOORE, 2004, p. 167). It is more than a simple preference toward something, for stating that the subject should adopt a will toward a specific goal implies representing that specific goal as the desirable good.

Gert Biesta did not discuss in detail this normative dimension of education in his ICPIC talk. Nevertheless, he pointed out the concept of responsibility, in a levinasian context, stating that the educational encounter with the Other awakes the subject through the (positive) experience of outside resistance. It is this resistance that will generate subjectness, meaning that it is the face of the Other that installs the moment where the self finds itself (BIESTA, 2015). It is only then that the subject is faced with his/her own responsibility to live in a desirable way, in relation to the life he/she lives with others on a planet that has limited capacity for fulfilling all the desires.

Biesta seems to identify tout court individual desires (that is, the desires that children have before going through the "strainer" of education) with the egological way of existence, referring to them negatively as "being-with-one-self". It is, in itself, a metaphysical and an anthropological statement that could be objected, but, in an educational framework, could it not also enable some forms of adult authoritarianism and children manipulation? 
P4C started, precisely, from Matthew Lipman's concern with helping children to deal with ambiguities - such as political propaganda and advertising empowering them to make conscious choices (LIPMAN \& MORIYÓN, 2011, p. 186). If, on the one hand, children are told that what they bring to education are, mainly, desires that will have to be interrupted, and that this interruption will be carried out by their teachers and educators; and if, on the other hand, teachers are told that "it is their responsibility to be educators and not learners" (see footnote 3 in Biesta's paper), how can we be sure that no hidden agendas are going to prevail? What happens to encounter and dialogue when only one of the parts involved has normative privileges?

Looking for a deeper understanding of this normative dimension of desires in G. Biesta's keynote talk took us to his 2014 challenging book, The beautiful risk of education. In this work, the normative approach is transversal and clearly stated: "education is always framed by purposes and thus by ideas about what good or desirable education is" (BIESTA, 2014, p. 120). In fact, to be able to make judgments about what is to be done (BIESTA, 2014, p. 8) or about what is educationally desirable (BIESTA, 2014, p. 129) is presented in the book as the central educational question.

The main concept here seems to be "judgment", the tool by which teachers and educators may practice what G. Biesta calls educational wisdom. Nurturing educational wisdom is presented as the purpose of teaching and, consequently, also the purpose of teaching education. Biesta refuses a technicist and reductionist approach to teaching, since it is not possible to predict in advance every particular situation. He, then, highlights the role of judgment to promote educational virtuosity (BIESTA, 2014, p. 120).

At this point, it seems again clear that G. Biesta considers that teachers and educators are the ones who have to learn how to recognize the standards for what is desirable in their practices, as well as in their students' behaviors. Since human beings - either students or teachers - are not robots with a predictable behavior, teaching education has to prepare future professionals for the ability to exercise 
judgment, identifying what can be rationally justifiable in terms of desires (BIESTA, 2014, p. 3).

With an explicit Aristotelian matrix, Biesta's virtue-based approach focuses now on the central role of the aims (or telos) of education. If teachers need to be educationally wise, they cannot lose sight of the bigger purposes of their activity. They need to permanently question, not only what education should be, but primarily what good education is (BIESTA, 2012)... just like archers who have a mark to aim at (ARISTOTLE, 1941, 1094a, p. 25). In this teleological perspective, the ideal teacher is someone who needs to be wise, having the ability to make situated judgments about what is educationally desirable.

How might, then, one become educationally wise? Biesta's book gives us some direct clues (BIESTA, 2014, pp. 135-136) by focusing teacher education in three major concerns: the formation of the whole person, the regular practice of judgment in relation to particular situations and the study of other teachers' virtuosity. Again, teachers are responsible for setting the standards, not students.

What about children's virtuosity? Is it not important for teachers to also study it? In justifying the (already identified as) controversial concept of "grownup-ness", G. Biesta stated that it is not a matter of age. However, the Aristotelian perspective on virtue is not primarily open to children, for it requires the experience and the appropriate decision procedure that the Greek philosopher considers to lack in younger ages (KOMASINSKI, 2017). How can we, then, avoid a dualistic reading of the educational environment, divided between the capricious child and the virtuous adult? If we do not, is there not a possibility that we end up complying with Aristotle's claims that desires, just like children, have to be made obedient, chastened and subjected to authority? (ARISTOTLE, 1941, 1191a-20).

Once here, we know that, according to G. Biesta, in education there are individual desires to suspend (or interrupt), justifiable conducts to draw on (or nurture) and wise ethos to develop. We also have some benchmarks that indicate the way to put this proposal into the professional practice of teachers.

But if the road that lies ahead of teachers and educators is clearly drawn, what can the menace be, the uncertainty implied in education? If there are 
evaluative standards according to which educators can orient their practices (either the responsibility in face of the Other or the ability to make good and wise judgments), how can one still talk about a risk in education? And what could that risk be?

In his 2014 book, G. Biesta presents the risk of education as the unpredictable character inherent in human freedom or the fact that educational processes do not work in a machine-like way (BIESTA, 2014, p. x).

But, we reaffirm, in face of the vindication of responsibility and educational wisdom as normative proposals presented in a clear and detailed fashion (although not articulated), can one say that there is still a place for risk? In Biesta's framework, can one really see education as the realm of a delicate equilibrium without a support network (a beautiful risk, as stated by the book's title), or is education (just) a controlled risk?

Could it be that the concept of risk has deeper meanings than the one we have just referred to? The attempt to explore this possibility took us on a different experience that we now share. It was a very rewarding one, for it was the scenario that made us go from addressing questions to the author to a commentary in the etymological sense of the word: co-mentare, Latin for "to think with".

I started writing this text on a weekend. And, as a mother of a 6-year-old girl, I had to explain to Isabel that I would not be able to play with her the whole Saturday because I had to work. She immediately offered to help me (a precious help, I might add) and we did some interesting thinking together on G. Biesta's idea of education as a risk. After some dialogue about the concept of risk, with various examples and questions about different types of risks (the lion as a risk for human life, abandoned glass on the forest as a serious risk for fire and destruction), we ended up with very few answers (meaning that the exchange opened up much more doors than the ones it closed down).

About 10 minutes later, Isabel returned to her toys. When I was already struggling with the computer to articulate the text, she came back to the flipchart where we had written our ideas previously. Playing with the words, she wrote the 
question that immediately made me rethink the normative dimension of education, but through a different perspective: is risk an education?

Building on Isabel's question, one could ask whether, instead of just thinking on the educational practice as a risk - in the sense of a fragile endeavor to be cared for -, risk could also be a desirable normative stand that should frame the ethos of educators and teachers. Instead of just being the predicate of educational activities, drawing the attention to the lack of safety nets (a negative concept), could there be a deeper layer from which to read the role of risk in education? Could it even nurture a desirable educational environment such as the community of philosophical inquiry?

In this line of thought, it seems possible to frame a positive reading of the experience of risk, as another meaning of what educational processes might be. A meaning that is fostered and encouraged by $\mathrm{P} 4 \mathrm{C}$, as we claim.

It is not just educational activities that represent a risk. The experience of risk might be educational as well and, therefore, educationally desirable: either for children or for educators. Knowing how to recognize risks and being receptive to the change that they can bring is, in itself, an occasion for getting a richer experience of the world.

There are, in fact, meanings of life that can only be apprehended in situations of risk for, as stated by Paulo Freire in his last book, as a presence in the world I run risks (FREIRE, 2004, p. 5). In this positive normative reading of risk, education could be the endeavor not just to take and accept the risks of not knowing everything that can happen in a pedagogical setting, as it is claimed in Biesta's work, but to build a process of human flourishing - to use an Aristotelian concept - that would be nurtured by the educational experience of a constitutive risk. If “There is no human existence without risk [...] Therefore - Freire claims - it is important that education, rather than trying to deny risk, encourages men and women to take it." (FREIRE, 2004, p. 5).

In what $\mathrm{P} 4 \mathrm{C}$ is concerned, namely in the community of inquiry framework (SHARP, 1987), practitioners welcome their own experiences as the driving force of inquiry. However, it should be highlighted, not in the sense of simple cognitive 
exercises (that "only stays in the head, not reaching the heart nor touching the soul"), for anything of interest might be invoked by the members of the community and provoke not just thinking, but also feeling and acting as a community (COSTA-CARVALHO; MENDONÇA, 2017).

In this context, communities of philosophical inquiry are loci where children and adults can (safely) deal with their own experiences, learning from those experiences and being transformed by them. Some of these experiences involve risks, not only figuratively, but also literally speaking. Almost since its beginnings, the community of inquiry as been an educational setting for violence reduction and prevention (LIPMAN, 1994; SPLITTER \& SHARP, 1995). Prévention de la violence et philosophie pour enfants (Center La Traversée, in Quebec), for example, is one of the most recognized and successful programs for violence prevention, using $\mathrm{P} 4 \mathrm{C}$ communities of inquiry.

Furthermore, from a pedagogical standpoint, to be ready to start educational practices from the children's experiences and interests might also represent a risky performance for the adult: the risk of dealing with the permanent pedagogical instability (LIPMAN, 2003, p. 87) of not knowing in advance what roads will be travelled. In what $\mathrm{P} 4 \mathrm{C}$ is concerned, this desirable instability is a symptom of the acknowledgment that, contrary to Biesta's assumption, there can not be an educator that is not also, and primarily, a learner.

\section{references}

ARISTOTLE. The Nicomachean Ethics. In: McKEON, R. (Ed.) The Basic Works of Aristotle. New York: Random House, 1941, p. 935-1112.

BIESTA, Gert. Boa educação na era da mensuração. Cadernos de Pesquisa, 42 (147), 808-825, 2012. Disponível em: <https:// dx.doi.org/10.1590/S0100-15742012000300009> Acesso em: 5 ago. 2017.

BIESTA, Gert. The beautiful risk of education. Colorado: Paradigm Publishers, 2014.

BIESTA, Gert. The rediscovery of teaching: on robot vacuum cleaners, non-egological education and the limits of the hermeneutical world view. Educational Philosophy and Theory, 48 (2), pp. 374-392, 2015.

BIESTA, Gert (2017). The beautiful risk of education. Disponível em <https://www.youtube.com/watch?v=QMqFcVoXnTI> Acesso em: 22. Jul. 2017. COSTA-CARVALHO, Magda; MENDONÇA, Dina. Thinking as a Community: Reasonableness and Emotions. In: GREGORY, M; HAYNES, J; MURRIS, K. (Eds.), The 
Routledge International Handbook of Philosophy for Children. New York: Routledge, 2017, pp. 127-134.

FREIRE, Paulo. Pedagogy of Indignation. New York: Routledge, 2004.

KOMASINSKI, Andrew. Ethics is for Children. Revisiting Aristotle's Virtue Theory. In: KENNEDY, D; BAHLER, B. (Eds.), Philosophy of Childhood today. Exploring the boundaries. London: Lexington Books, 2017, pp. 39-51.

LIPMAN, Matthew. Educating for violence reduction and peace development. Ile Congrès Mondial sur la Violence. Actes du Congrès. CAUCHY, V. (Eds.), Montréal: Éditions Montmorency, 1994, pp. 363-378.

LIPMAN, Matthew, Thinking in Education, Cambridge: Cambridge University Press, 2003. LIPMAN, Matthew; Moriyón, Felix. Matthew Lipman: una biografía intelectual. Haser. Revista Internacional de Filosofía Aplicada, 2, pp. 177-200, 2011.

MOORE, G. E. Principia Ethica. London: Dover Philosophical Classics, 2004.

SHARP, Ann Margaret. What is a community of inquiry? Journal of Moral Education, 16 (1), pp. 37-45, 1987.

SPLITTER, Laurance; SHARP, Ann Margaret. Teaching for better thinking. Hawthorn: ACER, 1995.

received in: 14.08 .2017

accepted in: 26.08.2017 